\title{
A Review of Project Life Cycle Management
}

\author{
Abhinand G. B. ${ }^{1}$, Abhinav Agrawal ${ }^{2}$, Dr. Prashant $\mathbf{S} \mathbf{H}^{3}$ \\ ${ }^{1,2}$ Research Scholars, Dept. of Mechanical Engineering, Sir M. Visvesvaraya Institute of Technology, Bengaluru, \\ Karnataka, India \\ ${ }^{3}$ Assistant Professor, Dept. of Mechanical Engineering, Sir M. Visvesvaraya Institute of Technology, Bengaluru,
}

Karnataka, India

\begin{abstract}
Product life cycle management (PLM) is the process of managing the entire lifecycle of a product from its inception through the engineering, design, and manufacture, as well as the service and disposal of manufactured products. PLM integrates people, data, processes and business systems and provides a product information backbone for companies and their extended enterprise. This article is about understanding and successfully manages a product's life cycle and how the company should develop strategies and methodologies like the Product Life Cycle Model Description, Analysis of Product Life Cycle Management, Product Life Cycle in Respect to The Technology Life Cycle and Use of Product Management for Successful Product Life Cycle.
\end{abstract}

Keywords: Product, Product Life cycle Management, Design, Analysis.

\section{INTRODUCTION}

Every service and product have different life cycles. The period from which the product's first launch into the market until its final withdrawal and split up in phases is called the life cycle. Changes are made in the way that the product is behaving into the market that is its refection in respect of sales to the company that introduced it into the market during this period. Product's life cycle management is very important since an increasing the profits is one of the major goals of the company that introduces a product into the market. Either the companies follow the basic rules of the different life cycle phase that are analysed later or use strategic planning.

The product's success or failure, its position in the market compared to other competitors and understanding and realise when it is time to introduce and withdraw a product from a market can be understood by studying the product life cycle management. For the company to completely understand the above and successfully manage a product's life cycle, the company has to develop strategies and methodologies which are discussed later on.

\section{METHODOLOGY}

2.1. Part 1: Product Life Cycle Model Description

The period of product's life cycle consists of five major steps or phases:

Product Life Cycle

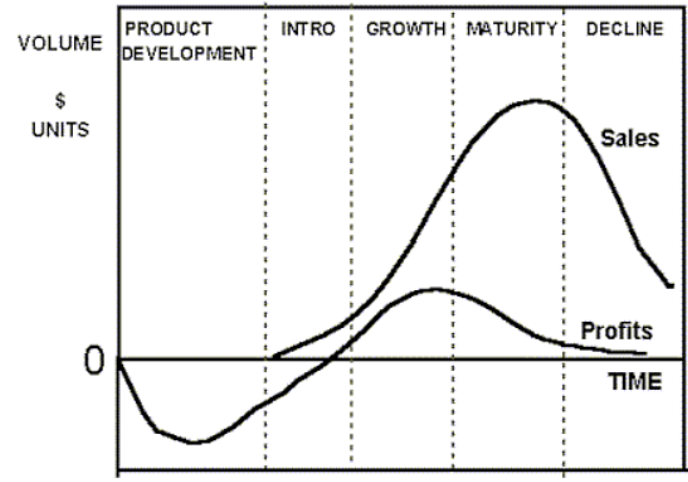

Fig. 1: Product Life Cycle Graph

\subsubsection{Product Development Phase}

When a company finds and develops a new product idea, product development phase begins. Translating various pieces of information and incorporating is involved into the new product. A product is usually undergoing several changes 


\section{International Advanced Research Journal in Science, Engineering and Technology}

Vol. 8, Issue 6, June 2021

DOI: $10.17148 /$ IARJSET.2021.8695

involving a lot of money and time during development, before it is exposed to target customers through test markets. The products which survive the test market are then introduced into a real marketplace and then the introduction phase of the product begins. Sales are zero and revenues are negative, during the product development phase. It is the time of spending with absolutely no return.

\subsubsection{Introduction Phase}

The product launch with its requirements to getting it launch in such a way so that it will have maximum impact at the moment of sale are included in Introduction phase of product. From actions taken by the company prior to the introduction of the product to the market results to a successful product introduction. The actions are included in the formulation Marketing strategies. During the product development, this is accomplished by the use of market research. Customer requirements on design, pricing, servicing and packaging are invaluable to the formation of a product design. A customer can tell a company what features of the product are appealing and what are the characteristics that should not appear on the product. He will also describe the ways of how the product will become handy and useful. In this way a company will know before its product is introduced to a market what to expect from the customers and competitors.

\subsubsection{Growth Phase}

Satisfaction of seeing the product take-off in the marketplace is offered by the growth phase. This is the right timing to focus on increasing the market share. If the product has been introduced first into the market, then it is in a position to gain market share relatively easily. A new growing market alerts the competition's attention [1].

Also, the Company must show all the products offerings and try to differentiate them from the competitor's ones. Managing the growth stage is essential. Companies sometimes should not consume more effort into the production process, overestimating their market position. Accurate estimations in forecasting customer needs will provide essential input into production planning process.

\subsubsection{Maturity Phase}

The maturity phase arrives, when the market becomes saturated with variations of the basic product, and all competitors are represented in terms of an alternative product. Instead of the growth of the market itself, in this phase market share growth is at the expense of someone else's business. This period is the period of the highest returns from the product. For example, "Tide" washing powder, which has grown old, and it is still growing [2]. A successful product maturity phase is extended beyond anyone's timely expectations.

\subsubsection{Decline Phase}

There is a lot of issues to be resolved before with decide to move it out of the market and the decision for withdrawing a product seems to be a complex task. To conceptualizing the decline signals of a product is difficult for a company. Usually with a decline of market sales a product decline is accompanied. The promotion should be pulled back at a level that will make the product presence visible and at the same time retain the "loyal" customer and the prices must be kept competitive.

\subsection{Part 2- Analysis of Product Life Cycle Management}

Some techniques in product life cycle management are there which can be very much helpful in optimizing the revenue growth of the product with respect to its life cycle and the position in a market. These techniques involve mostly the management and marketing strategies that are being used by almost every company nowadays. It also includes the knowledge about upgradation of the product along with its replacement and termination in the market. Product life cycle of a model must be theoretically analysed to embrace these techniques and strategies.

The model of Product life cycle as discussed in the previous section was highly debated over in the early 80 s by various authors. The reasons are described below:

a. Changes in demand for a product over time make it very difficult to differentiate the phases of a product's life cycle, their duration almost impossible to predict, and the level of product sales is somewhat imaginary.

b. There are many products that do not follow the usual shape of the product life cycle graph as shown in fig. 1

c. The life cycle of the product does not depend entirely on time. 


\section{International Advanced Research Journal in Science, Engineering and Technology}

Vol. 8, Issue 6, June 2021

DOI: $10.17148 /$ IARJSET.2021.8695

This also depends on few other parameters like market trends, management policy and strategic decision of the company. It is very difficult to pinpoint all these parameters and then evaluate accordingly and hence it is not included in the product life cycle as described in the previous section.

The type of any particular product also varies the Product life cycle. There are so many different models and so many different marketing approaches. There are basically three different types of products: a product class (such as bikes), a product form (such as a standard, sports, touring bike etc of a particular industry) and a product brand of that particular industry (such as Yamaha/Honda).

The life cycle of the product class sees a fluctuation in the market trends and lasts longer than the life cycle of the product form or brand while on the other side the life cycle of a product form or brand refers to the competitiveness of the company (that is quality, profit etc) and hence it is more closely related to the product life cycle model.

A product manager must know which stage of its life cycle a product is in, regardless of the problems in the model discussed above. There is a good way to do this suggested by Donald Clifford in 1965, which is as follows:

- Detailed studied data about the product's behavior in a span of 3 - 5 years should be collected which contains the information about sales, price, profits, market values and return of investment.

- Competitor's analysis with respect to market share should be done.

- Information about the life cycle of the similar products should be collected.

- Estimation of sales in a span of $3-5$ years after the product launch should be done.

- Competitors short term strategies should also be analyzed which consists of emerging products, plant upgrade and production increase.

Few strategies to be applied when the phase of product life cycle is recognized.

\subsection{Part 3: Product Life Cycle In Respect To The Technology Life Cycle}

As the new technology matures so will the product or service that uses this technology. Changes that occur during a technology life cycle has a unique reflection on the customers and so on the product life cycle.

Since in the early days of a new technology, early adopters and technology enthusiasts drive a market as they demand just technology. By many companies this drive and demand is translated as the introduction phase of a new product. Customers become more conservative and demand quick solutions and convenience, as technology grows old.

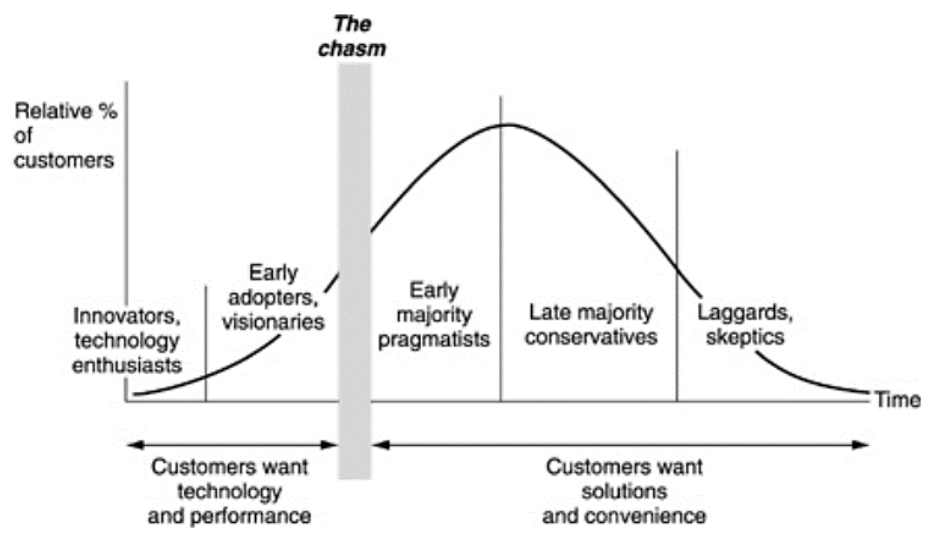

Fig. 2: Change in customers as technology matures

The difference between the early and late adopters the "chasm" shown in the graph above is depicted. Each is translated to a product's different phase of its life cycle and each needs different marketing strategies. The greatest percentage of customers in a market is held by the late adopters. This is the reason why most products start their life cycle as technology driven. Then they change into customer driven as time passes by. A good example of this is the computer market. In one 


\section{International Advanced Research Journal in Science, Engineering and Technology}

Vol. 8, Issue 6, June 2021

\section{DOI: $10.17148 /$ IARJSET.2021.8695}

hand customers ask for ease of use, convenience, short documentation and good design. On the other hand, customers rush out to purchase anything new regardless of its complexity. This is why companies in the computer industry withdraw their products long before they reach their maturity phase [6]. This is the moment that a product reaches its peak that is the time that both early and late adopters buy the product.

\subsection{Part 4: Use of Product Management for Successful Product Life Cycle}

Product management is a mid-level management function that can be used to manage the product life cycle and enable the company to make all the decisions required during each phase of the product life cycle. The moment a product is introduced and withdrawn is defined by the product manager's use of product management.

A product manager exists for three basic reasons. For starters he manages the revenue, profit, forecasting, marketing and developing activities related to a product during its life cycle. Secondly, since winning a market requires a deep understanding of the customer, he identifies the unfulfilled needs of the customers and hence he takes decisions for the development of certain products which match the customers and hence the needs of the market. In the end he provides direction to the internal organization of the company as he can be the eye and ear of the product path during its life cycle.

\subsubsection{Understand how product management works:}

When responsible for a given new product, the product manager needs to know about the product, the market, customers and competitors, in order to give the van instructions that lead to a successful product. He should be able to manage the production line as well as the marketing of the product. When the product manager does not have any specific authority over the people involved in the new product, he or she needs to gather the necessary resources for the organization to meet the product goals. He needs to know where to look and how to get the necessary expertise for product success.

\subsubsection{Maintain a Product/Market Balance:}

The person who will create a new product in order to work as a product manager needs to understand and have a strong understanding of the customer/market needs and therefore make the right decisions on market introduction, product life cycle and product cannibalism. To achieve the above he must balance the needs of the customers with the capabilities of the company. Also, he needs to balance product goals with company objectives. The way to measure the success of a product depends on where the product is in its life cycle. Therefore, the product manager must understand the strategic direction of the company and translate it into the product strategy and product life cycle position.

\subsubsection{Treat Product Management as a Discipline:}

Management of a product should not be taken as a part-time job or task. It needs constant monitoring and review. Having said that, it is not clear why many companies do not treat product management as a discipline. The answer lies in the fact that product management is not taught as engineering or accounting i.e., no formal training.

\section{RESULTS AND DISCUSSION}

It is obtained that the life of a product can be split into various phases from the product's first launch until its final withdrawal namely from the Product Development phase to the Decline phase. The sales and the Profits were the highest during its Maturity phase and the Growth phase respectively as shown in Fig. 1.

Analysis of the PLM is very necessary in order to optimize the revenue growth. Along with time it also depends on various factors like change in demand, type of product etc. so a detailed analysis of data collected over a span of 3-5 years should be done which contains information about revenue, profits, market shares, and the strategies of competitors should also be taken care.

One of the most important factors that affect PLM is Technology. Customer's demand of rapid solutions and more convenience leads to technology growth. The 'Chasm' differentiates the early adopters and the late adopters as shown in Fig. 2. Mostly products enter the market as technology driven but with time, they transform to be customer driven. This is because the market hold is maximum for the late adopters only as shown in Fig.2.

After the analysis of all the factors affecting Product life cycle, decision making and implementation becomes the responsibility of the product management team. A product manager should have a deep knowledge of not just the product but also the customer's demands and the market. He has to manage the revenue, forecasting, developing activities etc. He should maintain product and market balance. And finally, he should treat product management as a discipline.

\section{CONCLUSION}

As per the preceding findings, the product life cycle management is very important. The PLM initiatives often miss their potential and make projects unnecessarily costly. That is good PLM capabilities are essential to accelerate the maturity growth in product development projects. This improves product design and cuts lead time and cost.

This paper concentrates on the different period a product goes through in the product's life cycle then the analysis of 


\section{International Advanced Research Journal in Science, Engineering and Technology}

Vol. 8, Issue 6, June 2021

DOI: $10.17148 /$ IARJSET.2021.8695

Product life cycle management. Also, the effect of change in Technology Lifecycle on the product's life cycle. Subsequently, the significant importance of the Product manager and how the roles of a Product Manager will result to a successful Product cycle.

\section{REFERENCES}

\section{Journals}

[1] Aaker D. Strategic Market Management, Willey, 1995.

[2] Avlonitis G. Strategic Industrial Marketing, Stanoulis, 2001.

[3] Barringer P. H. "Why you need practical reliability details to define life cycle costs

[4] Clifford D. "Managing the Product Life Cycle", European Business Journal, July1969.

[5] Cox W. E. "Product Life Cycles as Marketing Models", The Journal of Business, p.p. 375-384, October 1967.

[6] Daft L. Organizational Theory and Design, West Publishing, St Paul Minnesota, 1992.

[7] Drummond G. Ensor J. Strategic Marketing: Planning and Control, Butterworth -Heinemann.

[8] Hata T. Sakamoto H. Kato S. Kimura F. Suzuki H. "Feasibility Study for Rapid

[9] Product Life Cycle", University of Tokyo, on-line, http://www.cim.pe.u-tokyo.ac.jp

[10]Jensch J. "Strategic Marketing and the Product Life Cycle", 1999,

[11]Life Cycle Strategies Inc. "Three Fundamentals for Effective Product Management: A

[12]Practical Guide for Improving Product Success", 1999

[13]Lightfoot W. "Product Life Cycle Stages", on-line http://www.marketinginc.com.

[14]McGrath M. Product Strategy of High-Technology Companies, McGraw-Hill, 2000.

[15] Ganeshappa K. "Production and Prospects of Agriculture -A case Study of Shimoga District of Karnataka". International Research Journal on Advanced Science Hub, 2, Special Issue ICSTM 12S, 2020, 111-115. doi: 10.47392/irjash.2020.271

[16] Sowmya Dhanalakshmi.C; Madhu P; Hemachandran N; Bharathkumaran G; Harisharvinth LB. "Design and fabrication of four-way hacksaw machine - A design thinking approach". International Research Journal on Advanced Science Hub, 2, 7, 2020, 126-130. doi: 10.47392/irjash.2020.76

[17]McNamara C. "Basic Overview of Organizational Life Cycles", on-line http://www.mapnp.org/library/org_thry/org_cycl.htm.

[18]Norman D. "The life cycle of a technology: Why it is so difficult for large companies to innovate", 1998, on-line, http://www.jnd.org.

[19]Yanjun Qian et al., Recent Advances in Concurrent Engineering Modeling, 5th International Asia Conference on Industrial Engineering and Management Innovation (IEMI 2014), pp.6-9, 2014.

[20]Jian, G., Oriet, L., Understanding and Implementation of Concurrent Engineering. The Proceedings of the 11th International Conference on Concurrent Enterprising. Munich, Germany, June 2005

[21]D. K. Pawar et. Al., "Concurrent Engineering: From Concept to Implementation," presented at the International Conference on Agile Manufacturing, Bangalore, 1996. 